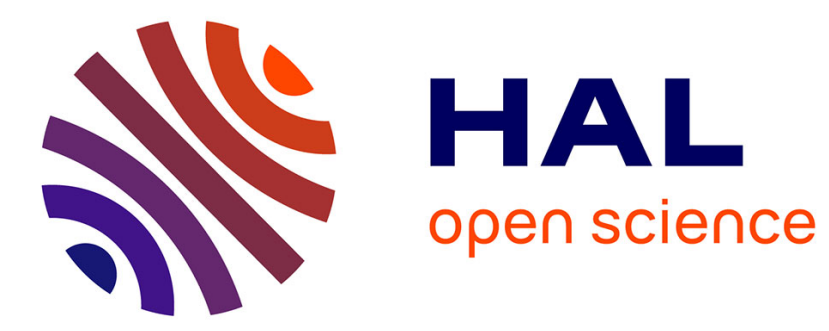

\title{
Contrasting impacts of grass species on nitrogen cycling in a grazed Sudanian savanna
}

Lambiénou Yé, Luc Abbadie, Gérard Bardoux, Jean-Christophe Lata, Hassan Bismarck Nacro, Dominique Masse, Henri de Parseval, Sébastien Barot

\section{- To cite this version:}

Lambiénou Yé, Luc Abbadie, Gérard Bardoux, Jean-Christophe Lata, Hassan Bismarck Nacro, et al.. Contrasting impacts of grass species on nitrogen cycling in a grazed Sudanian savanna. Acta Oecologica, 2015, 63, pp.8-15. 10.1016/j.actao.2015.01.002 . hal-01112092

\section{HAL Id: hal-01112092 https://hal.sorbonne-universite.fr/hal-01112092}

Submitted on 2 Feb 2015

HAL is a multi-disciplinary open access archive for the deposit and dissemination of scientific research documents, whether they are published or not. The documents may come from teaching and research institutions in France or abroad, or from public or private research centers.
L'archive ouverte pluridisciplinaire HAL, est destinée au dépôt et à la diffusion de documents scientifiques de niveau recherche, publiés ou non, émanant des établissements d'enseignement et de recherche français ou étrangers, des laboratoires publics ou privés. 


\section{Contrasting impacts of grass species on nitrogen cycling in a}

2 grazed Sudanian savanna

3 Lambiénou Yé ${ }^{\text {a,b,d }}$, Luc Abbadie ${ }^{\text {d }}$, Gérard Bardoux ${ }^{c}$, Jean-Christophe Lata ${ }^{\text {d,f }}$, Hassan

4 Bismarck Nacro $^{\mathrm{b}}$, Dominique Masse ${ }^{\mathrm{e}}$, Henri de Parseval ${ }^{\mathrm{d}}$, Sébastien Barot ${ }^{\mathrm{a}}$

6 a IRD, UMR 7618, IEES-Paris, 46 Rue d'Ulm, 75230 Paris, France. e-mail:

7 ylambienou@yahoo.fr

8 b IDR, Université Polytechnique de Bobo-Dioulasso, Burkina Faso

$9 \quad{ }^{\mathrm{c}}$ CNRS, UMR 7618, IEES-Paris, Bât. EGER, 78850 Thiverval-Grignon, France

$10{ }^{\mathrm{d}}$ Sorbonne Universités, UPMC Univ Paris 06, UMR 7618, IEES-Paris, 46 Rue d’Ulm, 75230

11 Paris, France

$12{ }^{\mathrm{e}}$ IRD, UMR 210 ECO\&SOLS, LMI IESOL, Centre ISRA-IRD de Bel-Air, Dakar, Sénégal

$13{ }^{\mathrm{f}}$ Department of Geoecology and Geochemistry, Institute of Natural Resources, Tomsk 14 Polytechnic University, 30, Lenin Street, Tomsk, 634050, Russia

\section{ABSTRACT}

We investigated the impact of perennial and annuals grass species on nitrogen cycling in a

Sudanian savanna of Burkina Faso. We also analyzed how the local context in terms of grazing and soil properties modifies these impacts. We selected four plots differing both by the intensity of grazing by cattle and soil depth, and used soil and grass biomass ${ }^{15} \mathrm{~N}$ as

21 integrative indicators of $\mathrm{N}$ cycle. If perennials are able to foster a more efficient nitrogen cycling there should be lower ${ }^{15} \mathrm{~N}$ abundances in their biomass and soil. If soil depth and cattle pressure significantly modify nitrogen fluxes, soil depth and cattle pressure should

24 influence ${ }^{15} \mathrm{~N}$ signatures. Our results suggest that perennial grasses are more conservative for nitrogen (inhibition of nitrification, less leaching via a perennial root system, slower cycling).

26 The increase in leaf $\delta^{15} \mathrm{~N}$ with $\mathrm{N}$ concentration is steeper in L. togoensis than in the three other 27 grasses. No significant difference was found between the ${ }^{15} \mathrm{~N}$ signatures of the four plots. Our 
results on ${ }^{15} \mathrm{~N}$ signatures and the fact that perennial grasses are much more abundant in the plots that are less grazed and have deeper soils, confirm that the switch from perennial to annual grasses is linked to a degradation in soil fertility and pasture quality. This suggests that ${ }^{15} \mathrm{~N}$ signatures can be used as indicators of fertility.

Keywords: ${ }^{15} \mathrm{~N}$, nitrogen cycling, savanna, perennial grass, annual grass, herbivore, Burkina Faso

\section{Introduction}

Plants influence nutrient cycling and their long term availability (Chapman et al., 2006; Hobbie, 1992), and this feedbacks on their own growth and primary productivity. This is achieved through many mechanisms (Hobbie, 1992; Knops et al., 2002). This allows them to cope with abiotic constraints of ecosystems such as the lack of mineral nutrients and contrasting soil types and with biotic constraints such as herbivory or competition between plants (Craine, 2009; Grime, 2001). Among all possible strategies, the distinction between perennial and annual plants is particularly relevant in terms of nitrogen cycle and competitive ability (Grime, 1977, 2001). Annuals are viewed as opportunistic. They need to acquire their resources as quickly as possible and benefit from the immediately available mineral resources. Perennials are more likely to influence local nutrient cycles and to benefit from such modifications because their root system, their root exudates and their litter (roots and leaves) interact for a longer period with the same patch of soil and soil micro-organisms living in this patch (Vinton and Burke, 1995). Perennials grow slower than annuals but may benefit from sparing soil mineral nutrient resources, from increasing the local availability of these resources and from decreasing nutrient losses. It has for example been shown in tropical 
savannas that many perennial bunch grasses are able to inhibit nitrification through the release of particular molecules from their root systems (Lata et al., 2004; Subbarao et al., 2007a; Subbarao et al., 2007b), which increases their own biomass (Boudsocq et al., 2009). As these grasses live for several tens of years, they build dense root systems where the close proximity between dead and live roots is likely to induce a very efficient nutrient recycling and reduce nitrogen losses (Abbadie and Lata, 2006; Abbadie et al., 1992). In this context, our primary goal was to compare, from the point of view of nitrogen cycling, two annual and two perennial bunch grasses growing in the same West African savanna.

To meet this goal, we measured the natural abundance in ${ }^{15} \mathrm{~N}$ of the biomass of these four grasses and of the soil penetrated by their root system. Indeed, ${ }^{15} \mathrm{~N}$ abundance is considered as a good indicator of ecosystem functioning (Dijkstra et al., 2008; Robinson, 2001; Staddon, 2004; Templer et al., 2007). First, ${ }^{15} \mathrm{~N}$ abundance is used to determine the origin of soil organic matter (Boutton et al., 1998; Danso et al., 1993). Similarly, the ${ }^{15} \mathrm{~N}$ of biomass gives hints on the origin of the nitrogen. For example legumes, due to symbiotic nitrogen fixation, tend to have lower concentrations in ${ }^{15} \mathrm{~N}$ than other plants and thus to decrease soil ${ }^{15} \mathrm{~N}$ concentration through their litter. Second, the isotopic fractionation due to the lower reactivity of ${ }^{15} \mathrm{~N}$ relatively to ${ }^{14} \mathrm{~N}$ allows tracing nitrogen fluxes in the soil. For example, rapid nitrogen cycling and nitrification are thought to increase ${ }^{15} \mathrm{~N}$ abundance (Dijkstra et al., 2008), while tighter nitrogen cycling (e.g. less leaching and denitrification) should lower ${ }^{15} \mathrm{~N}$ abundances. The difference between plant and soil ${ }^{15} \mathrm{~N}$ abundances gives hints on plant preference for ammonium vs. nitrate (Kahmen et al., 2008). Similarly, the discrepancy between the ${ }^{15} \mathrm{~N}$ signatures of the biomass of an African perennial bunch grass and bulk soil (lower ${ }^{15} \mathrm{~N}$ in the biomass than in the soil organic matter) (Abbadie et al., 1992) suggested that this grass fosters an efficient nitrogen cycling through the recycling of the nitrogen contained in the roots of its dense and localized root system. Taken together, we 
77 predict that our two perennial and two annual grasses should have different ${ }^{15} \mathrm{~N}$ signatures, 78 which should in turn impact soil signatures. For the same reasons the universal positive correlation between leaf ${ }^{15} \mathrm{~N}$ signature and leaf $\mathrm{N}$ concentration (Craine et al., 2009b) should also be different between annual and perennial biomasses.

Besides plant influence on nitrogen cycling, other factors such as herbivory and soil properties are likely to impact these cycles, which should in turn modify ${ }^{15} \mathrm{~N}$ isotopic signatures. Cattle or wild herbivores indeed quicken carbon and nutrient cycling by increasing the turnover of the biomass. Herbivore impact on nutrient cycling has been extensively studied. On the one hand, an important issue is to determine whether herbivores could increase the efficiency of nitrogen cycling (decrease nitrogen losses), which could increase primary production on the long term (de Mazancourt et al., 1998). On the other hand, they have been shown to impact many fluxes of mineral nitrogen but the direction of these effects is likely to be case dependent (McNaughton et al., 1997; Wardle et al., 2001). For example, cattle have been shown to increase nitrification, denitrification and free nitrogen fixation in a temperate grassland (Patra et al., 2006). In turn, the modification of these fluxes impacts ${ }^{15} \mathrm{~N}$ signatures and may either increase (Frank and Evans, 1997) or decrease (Frank et al., 2000) soil ${ }^{15} \mathrm{~N}$ abundances. Similarly, soil properties such as soil depth, soil compaction, soil texture or soil organic matter content are likely to impact biomass and soil ${ }^{15} \mathrm{~N}$ signatures (Abadín et al., 2010) through their effects on soil capacity to retain mineral nutrients, or through their effects on microbial biomass and activities.

Taking into account these interactive impacts of plant species and soil type/herbivores on nitrogen cycling and detecting these interactions using ${ }^{15} \mathrm{~N}$ signatures is interesting in two contrasted ways. On the one hand, such complex interactions could strongly increase the variability in isotopic signatures, which could blur potential effects of targeted treatments (here the plant species). Documenting these interactions and their effects on isotopic 
signatures is thus methodologically useful to help designing and interpreting other

103 experiments or field samplings. On the other hand, isotopic signatures might allow analyzing

104 the impact of herbivores and different soil types on nitrogen cycling and might help

105 disentangling the interactions between herbivores or soil types and plant species.

106 For these reasons, we compared two annual and two perennial grasses in a West

107 African savanna where both soil depth and cattle pressure are varying. Taken together, we

108 make the following predictions. If perennials are able to foster a more efficient nitrogen

109 cycling, (1) there should be lower ${ }^{15} \mathrm{~N}$ abundances in their biomass and soil and (2) the

110 relation between ${ }^{15} \mathrm{~N}$ signature and $\mathrm{N}$ concentration should be different between annual and

111 perennial leaf biomass. If soil depth and cattle pressure significantly modify nitrogen fluxes,

112 (3) soil depth and cattle pressure should influence ${ }^{15} \mathrm{~N}$ signatures, (4) plant species and soil

113 depth or cattle pressure should affect ${ }^{15} \mathrm{~N}$ signatures in an interactive way, i.e. the impact of 114 each species should depend on soil depth and cattle pressure.

\section{2. Material and methods}

116 2.1. Study site

The study site is the third management unit of the protected forest of Dindéresso

118 (FCD) in the West of the town of Bobo-Dioulasso, at the altitude of $390 \mathrm{~m}\left(11^{\circ} 12.494^{\prime}\right.$ north,

$1194^{\circ} 24.159^{\prime}$ west). The climate is South-Sudanian: there is a wet season from May to October

120 and a dry season from November to April. The area is located between the 900 and $1250 \mathrm{~mm}$

121 isohyets. $1254 \mathrm{~mm}$ of rain fell in 2010 but only $831 \mathrm{~mm}$ in 2011 . The mean annual

122 temperature is $28^{\circ} \mathrm{C}$. The whole forest lies on sedimentary rocks and our own study area lies

123 on Bobo-Dioulasso sandstone. Soils are tropical ferruginous leached soils indurated or not.

124 Vegetation consists in a shrub savanna grazed by cattle. It is characterized by the following 
dominant shrub/small tree species: Vitellaria paradoxa, Terminalia laxifolia, Detarium

126 microcarpa, Parkia biglobosa, Guiera senegalensis, Combretum nigricans, Gardenia ternifolia. The herbaceous layer is dominated by grasses. The main annual grasses are Andropogon pseudapricus, Loudetia togoensis, Microchloa indica. The main perennial

129 grasses are Andropogon gayanus, Andropogon ascinodis, Hyparrhenia subplumosa,

130 Schizachyrium sanguineum and they are all bunch grasses. There are some legumes (Cassia

131 mimosoides, Indigofera trichopoda, Zornia glochidiata, Tephrosia pedicelata, Tephrosia

132 bracteolate), Cyperaceae (Fimbristylis hispidula) and other forbs (Waltheria indica, Pandiaka

133 heudelotii, Spermacoce stachydea, Striga hermonthica). Grass aboveground biomass and

134 necromass are burnt each year by bushfires.

135 The study site has been divided in four blocs of approximately 1.5 ha according to the

136 dominance of perennial and annual grasses and the frequency of grazing: blocs 1 and 2 are

137 dominated by annual grasses and are more grazed by cattle during the rainy season while

138 blocs 3 and 4 are dominated by perennial grasses and are less grazed during the rainy season.

139 Blocs 1 and 2 are indeed next to the main road, so that they are more easily reached by cattle

140 and shepherds, and blocs 3 and 4 are supposed to host an abundant population of tsetse flies

141 during the rainy season so that they are avoided to limit the risk of cattle infection by

142 trypanosomiasis. Blocs 1 and 2 have shallower soils (at most $55 \mathrm{~cm}$ deep, they are indurated

143 ferruginous leached soils). Blocs 3 and 4 have deeper soils (at least $105 \mathrm{~cm}$ deep, the

144 indurated layer is deeper). Blocs 1 and 2 are contiguous and so are blocs 3 and 4. Blocs 1-2 145 and 3-4 are separated by a distance of about $2000 \mathrm{~m}$.

\section{$146 \quad$ 2.2. Soil and biomass sampling}

147 The study focusses on four of the dominant grass species: Andropogon pseudapricus,

148 Loudetia togoensis (annuals), Andropogon ascinodis and Andropogon gayanus (perennial 
149 bunch grasses). The four grasses are cespitosus but the tussocks of the two perennials are

150 much larger than the ones of the two annuals. The four species have $\mathrm{C}_{4}$ photosynthesis

151 (Breman and De Ridder, 1991). As a control, bare soils were also sampled. In each of the four

152 blocs, 2 or 3 replicates of each plant species or bare soil areas were randomly selected: an

153 individual for perennial bunch grasses, a small patch covered of individuals of the same

154 species for annuals and a small patch deprived of plants for bare soils. In total, 10 replicates

155 were sampled for each species and bare soils and they were spread over the 4 blocs. Taken

156 together, 50 sampling units (plant species or bare soil) were investigated. In each sampling

157 unit a soil sample was collected in June 2011 from the $0-10 \mathrm{~cm}$ layer using a core auger $(5 \mathrm{~cm}$

158 diameter). This sample was taken in the middle of tussocks for perennial grasses. Soil samples

159 were then air dried in the shade and sieved at $2 \mathrm{~mm}$. Leaves and roots were collected from

160 each annual or perennial grass sampling unit. Roots were collected using a core auger $(5 \mathrm{~cm}$

161 diameter) and washed with water. Leaves and roots were oven-dried at $70^{\circ} \mathrm{C}$ for 72 hours. In

162 total, 40 samples of roots, leaves and soil were analyzed as well as 50 soil samples (40

163 samples for annual and perennial grasses and 10 for bare soils).

\subsection{Soil and biomass analyses}

Soil and biomass samples were thinly ground and their content in $\mathrm{N}, \mathrm{C},{ }^{15} \mathrm{~N}$ measured

166 by EA-IRMS (Carlo-Erba NA-1500 NC Elemental Analyser on line with a Fisons Optima

167 Isotope Ratio Mass Spectrometer). As usually done (Wang et al., 2010), the contents in ${ }^{15} \mathrm{~N}$ 168 was expressed as relative differences in the ratios ${ }^{15} \mathrm{~N} /{ }^{14} \mathrm{~N}$ between samples and international 169 standards:

$$
\left.\delta^{15} \mathrm{~N}(\%)=\left(\left({ }^{15} \mathrm{~N} /{ }^{14} \mathrm{~N}\right)_{\text {sample }} /\left({ }^{15} \mathrm{~N} /{ }^{14} \mathrm{~N}\right)_{\text {standard }}\right)-1\right) 1000,
$$

171 The international standard for $\mathrm{N}$ is the atmospheric $\mathrm{N}_{2}$. 
All variables were analysed using ANOVAs testing for the effect of the bloc, the grass species and the interaction between the two (Tables 1 and 2). When the interaction was not significant it was removed from the model. When only simple effects were significant the direction of their effects was determined using the estimated model parameters and post-hoc Tukey tests. When the interaction was significant the variable was reanalyzed separately for 178 each grass species (or bare soil). Graphs (Figure 1-2) only display results for factors and

179 factor combinations that are significant. The relation between biomass $\delta^{15} \mathrm{~N}$ and $\mathrm{N}$ concentration was studied using ANCOVAs testing for the effect of $\mathrm{N}$ concentration, the effect a categorical variable (root vs. leaves or the grass species) and the interaction between the two. All these analyses were achieved using R software ( $\mathrm{R}$ development core team, 2010).

\section{Results}

Soil $\delta^{15} \mathrm{~N}$ is significantly lower (Tab. 1 and Fig. 1) for the two perennial species (respectively 3.98 and $3.88 \%$ for A. ascinodis and A. gayanus, see Table 3 for all values) than for the two annual species and the bare soil (respectively $4.38,4.55$ and $4.56 \%$ for $A$. pseudapricus and L. togoensis and bare soil), but is not affected by the bloc. This corresponds to a decrease in $\delta^{15} \mathrm{~N}$ of about $0.57 \%$.

Soil $\mathrm{N}$ concentration is affected by the interaction between the grass species and the bloc: under $A$. ascinodis $\mathrm{N}$ concentration is higher in blocs 1 and 3 than in blocs 2 and 4 ,

191 under A. pseudapricus it is higher in blocs 3 and 4 than in blocs 1 and 2, and under $L$.

192 togoensis it is higher in blocs 1 and 4 than in blocs 2 and 3. Soil C concentration is affected by

193 the interaction between grass species and the bloc (Fig. 2, Tab. 1): under A. pseudapricus it is 194 higher in blocs 3 and 4 than in blocs 1 and 2, under L. togoensis it is higher in blocs 1 and 4 than in blocs 2 and 3. 
Biomass $\delta^{15} \mathrm{~N}$ is overall higher under the two annual than under the two perennial

197 grasses (Fig .1 and Table 2). Both for roots and leaves there is a significant effect of species 198 and the bloc on biomass $\delta^{15} \mathrm{~N}$ but the interaction between these two factors is not significant 199 (Tab. 2). For roots, the $\delta^{15} \mathrm{~N}$ is higher (Fig. 2) in the two annuals (respectively 2.60 and 1.26 \%o for A. pseudapricus and L. togoensis) than in the two perennials (respectively -0.72 and $0.99 \%$ for $A$. ascinodis and A. gayanus) and in bloc 1 than in blocs 3 and 4 (respectively $2021.44,-0.17$ and $-0.09 \%$ for blocs 1,3 and 4). This corresponds to an increase in $\delta^{15} \mathrm{~N}$ of about 203 $2.8 \%$ between perennials and annuals. For leaves, the $\delta^{15} \mathrm{~N}$ is higher (Fig. 2) in $A$. pseudapricus (2.74) than in the three other species (respectively $0.67,-0.59$ and $-0.30 \%$ for L. togoensis, A. ascinodis and A. gayanus) and in blocs 1 and 2 than in bloc 4 (respectively 1.74, 1.18 and $-0.53 \%$ for blocs 1,3 and 4). Overall, the results on soil and biomass $\delta^{15} \mathrm{~N}$ support our hypothesis that perennial grasses lead to lower $\delta^{15} \mathrm{~N}$ than annuals (first hypothesis in the Introduction). However, these results are at odds with our third and fourth hypothesis. Both for roots and leaves there is a significant effect of species and the bloc on the biomass $\mathrm{N}$ concentration but the interaction between these two factors is not significant (Tab. 2). Root $\mathrm{N}$ concentration is higher (Fig. 2) in the two annuals (respectively 4.09 and $3.65 \mathrm{mg}$ $212 \mathrm{~g}^{-1}$ for A. pseudapricus and L. togoensis) than in the two perennials (respectively 2.52 and $3.71 \mathrm{mg} \mathrm{g}^{-1}$ for A. ascinodis and A. gayanus) and in blocs 1, 2, 3 (respectively 3.39, 3.72 and $\left.2143.13 \mathrm{mg} \mathrm{g}^{-1}\right)$ than in bloc $4\left(2.77 \mathrm{mg} \mathrm{g}^{-1}\right)$ and higher in bloc 2 than in bloc 3 . This corresponds 215 to an increase in $\mathrm{N}$ root concentration of about $48 \%$ between perennials and annuals. Leaf $\mathrm{N}$ 216 concentration, as $\delta^{15} \mathrm{~N}$, is higher (Fig. 2) in A. pseudapricus (10.55 $\mathrm{mg} \mathrm{g}^{-1}$ ) than in the three 217 other species (respectively 6.32, 6.20 and $7.41 \mathrm{mg} \mathrm{g}^{-1}$ for L. togoensis, A. ascinodis and A. 218 gayanus) and in blocs 2 and 3 than in bloc 4 (respectively 8.24, 8.26 and $6.41 \mathrm{mg} \mathrm{g}^{-1}$ for blocs 219 2, 3 and 4). 
A first ANCOVA shows that there is an overall positive effect of the biomass $\mathrm{N}$ 221 concentration on the $\delta^{15} \mathrm{~N}$ and that the slopes of the relation between the two variables is steeper for roots than for leaves (Fig. 3). A second ANCOVA shows that for roots, the relation is the same for all species $\left(\delta^{15} \mathrm{~N}=1.95 \mathrm{~N}_{\mathrm{R}}-5.64\right.$, where $\mathrm{N}_{\mathrm{R}}$ is the root biomass $\mathrm{N}$ concentration). A third ANCOVA shows that for leaves the relation varies significantly between species (Fig. 3): the slope is steeper for L. togoensis $\left(\delta^{15} \mathrm{~N}=1.33 \mathrm{~N}_{\mathrm{L}}-7.74\right.$, where $\mathrm{N}_{\mathrm{L}}$ is the leaf biomass $\mathrm{N}$ concentration) than for the three other species $\left(\delta^{15} \mathrm{~N}=0.50 \mathrm{~N}_{\mathrm{L}}-3.78\right)$. These results only partially support our second hypothesis (see the Introduction). We also checked that the bloc does not influence the relation between $\delta^{15} \mathrm{~N}$ and $\mathrm{N}$ concentration in roots and leaves.

\section{Discussion}

Our results support, at least partially, two of the hypotheses (the first and the second) we set in our introduction: (1) ${ }^{15} \mathrm{~N}$ signatures suggest that perennial and annual grasses do not 233 have the same impact on nitrogen cycling. (2) The increase in leaf $\delta^{15} \mathrm{~N}$ with $\mathrm{N}$ concentration

234 is steeper in L. togoensis than in the three other grasses. (3) ${ }^{15} \mathrm{~N}$ signatures do not allow to 235 point at any overall effect (whatever the grass species) of cattle grazing or soil depth on grass 236 functioning or nitrogen cycling. (4) ${ }^{15} \mathrm{~N}$ signatures do not suggest any interaction between 237 grass species and blocs that would affect nitrogen cycling.

\subsection{Impact of grasses on $\delta^{15} \mathrm{~N}$}

The $\delta^{15} \mathrm{~N}$ values are higher in the soil of annual grasses and bare soil than in the soil of 240 perennial grasses and, consistently, the same qualitative pattern is found for the $\delta^{15} \mathrm{~N}$ of the 241 grass biomasses. Since the source of nitrogen should be overall the same for plants growing 242 next to each other, this pattern must be due to fine scale differences between species in the 
243 various nitrogen fluxes leading to isotopic fractionation. The observed higher soil $\delta^{15} \mathrm{~N}$ under 244 annual grasses and in bare soil can be interpreted as an indicator of increased rates in nitrogen 245 cycling (mineralization, nitrification and denitrification) that also foster nitrogen losses 246 (Nacro et al., 2004; Templer et al., 2007; Templer et al., 2008). Indeed, fractionation likely 247 leads to an enrichment of the residual pool in ${ }^{15} \mathrm{~N}$ because ${ }^{14} \mathrm{~N}$, the lighter of the two stable 248 isotope, is more reactive (Mariotti et al., 1981). Thus, in the case of increased rates of nitrogen 249 cycling, ${ }^{14} \mathrm{~N}$ is more likely to leave the ecosystem through denitrification and leaching, which 250 leads to an increase in soil $\delta^{15} \mathrm{~N}$.

This interpretation is fully compatible with a previous study (Abbadie et al., 1992) that 252 compared the ${ }^{15} \mathrm{~N}$ signature of soil below perennial bunch grasses $(+3.4 \%$ ) and between 253 these grasses, i.e. a bare soil situation (about $+5 \%$ ). Here, we found qualitatively the same 254 difference $(+4.0 \%$ for perennials vs. $+4.5 \%$ for annuals and bare soils $)$ that can be 255 interpreted as in (Abbadie et al., 1992). There are differences in nitrogen fluxes and 256 fractionation between the soil below perennial grass tufts and the soil between these tufts or 257 below annuals grasses. These differences allow differences in ${ }^{15} \mathrm{~N}$ signatures to build up 258 slowly along the several tens of years of the life of these perennials. Indeed, the soil below 259 grass tufts gets slightly impoverished in ${ }^{15} \mathrm{~N}$ (relatively to the soil between tufts or below 260 annuals), grasses take up this nitrogen so that the biomass of their root also gets impoverished 261 in ${ }^{15} \mathrm{~N}$, some roots die and release mineral nitrogen impoverished in ${ }^{15} \mathrm{~N}$, differences in 262 fractionation further decrease the ${ }^{15} \mathrm{~N}$ signature of the nitrogen that can be absorbed by other 263 roots of the same grass tuft, and so on...

264 Other studies have shown that soil and biomass $\delta^{15} \mathrm{~N}$ values depend on plant species 265 (Kahmen et al., 2008; Kriszan et al., 2009; Nadelhoffer et al., 1996; Templer et al., 2005; 266 Wang et al., 2010). As hypothesized in the introduction, we suggest that perennial grasses are 267 able to influence the nitrogen cycle in a way that increases the availability of nitrogen in their 
268 favor. The fact that $\delta^{15} \mathrm{~N}$ values of bare soils are identical to the values of annual grasses 269 supports this rationale. Several mechanisms leading to a lower fractionation below perennial 270 bunch grasses than between these grasses and below annuals are probably leading to this 271 general pattern: (1) Many African perennial bunch grasses (e.g. Hyparrhenia sp., Brachiaria 272 sp.) have been shown to inhibit nitrification (Lata et al., 2004; Subbarao et al., 2007a; 273 Subbarao et al., 2007b). Perennial grasses are able to build a dense and perennial root system 274 so that (2) the proximity between dead and living roots reduces the risk of leaching of the 275 mineral nitrogen released by root decomposition (Abbadie and Lata, 2006; Abbadie et al., 276 1992) and (3) rates of leaching are likely to be further decreased by the fact that living roots 277 are always present and able to take up available mineral nutrients (Joffre, 1990). Testing fully 278 our hypotheses and interpreting thoroughly the ${ }^{15} \mathrm{~N}$ signatures will off course require (1) 279 documenting precisely nitrogen fluxes such as nitrification and denitrification potentials, (2) 280 measuring the ${ }^{15} \mathrm{~N}$ signatures of all nitrogen sources, (3) taking into account mechanisms that 281 could complicate the interpretation of ${ }^{15} \mathrm{~N}$ signatures such as nitrogen fixation by free bacteria 282 or endophytes (Elbeltagy et al., 2001).

\subsection{Impact of soil and herbivores on $\delta^{15} \mathrm{~N}$} et al., 2000) and soil properties (Abadín et al., 2010) have often been shown to impact soil $286 \delta^{15} \mathrm{~N}$, which is an indication of modifications of nitrogen cycling. In particular, herbivores impact nitrogen cycling and aboveground-belowground linkages both directly through changes in plant growth and physiology and alterations of the quality and quantity of mineral and organic resources and, indirectly, through changes in the functional composition of 290 vegetation (Bardgett and Wardle, 2003). Here, the species-specific $\delta^{15} \mathrm{~N}$ of the soil does not 291 depend on the four blocs while root and leaf $\delta^{15} \mathrm{~N}$ tends to be higher in the blocs with the 
higher cattle pressure (and shallower soil). This suggests (1) that increasing cattle pressure

293 and decreasing soil depth has a relatively weak direct effect on nitrogen cycling and/or that

294 this effect is recent (effects on biomass $\delta^{15} \mathrm{~N}$ but no effect on soil $\delta^{15} \mathrm{~N}$ ), (2) that this effect

295 tends to increase the rate of nitrogen cycling and nitrogen losses (Dijkstra et al., 2008;

296 Templer et al., 2007).

297 Besides, our sampling design is based on measurements made at the scale of

298 individual tufts for perennial grasses and small mono-specific patches for annual grasses and

299 we investigated equally the same four grass species in the four blocks. In fact, grazing

300 pressure and soil depth do not change the impact of each grass species on soil $\delta^{15} \mathrm{~N}$ but these

301 factors likely strongly impact nitrogen cycling and ${ }^{15} \mathrm{~N}$ signatures, indirectly, through their

302 effects on vegetation. Perennial grasses are dominant in the two blocs with deeper soils and

303 lower grazing pressures, while annual grasses are dominant in the two other blocs. This would

304 be the hint that cattle and shallow soils slow down or even reverse the normal succession,

305 which is one of the main mechanisms through which herbivores impact ecosystem

306 functioning (Bardgett and Wardle, 2003). Indeed, annuals normally start to grow in fallows

307 and are progressively replaced by perennials (Bilgo et al., 2006; Somé, 1996). Thus, overall,

308 at the scale of the whole savanna lower soil depth and higher cattle pressure lead to higher

$309 \delta^{15} \mathrm{~N}$ values through a switch in the dominant grass species (see the first section of the

310 Discussion). Note that the direct effects of cattle pressure also lead to an increase in $\delta^{15} \mathrm{~N}$, at

311 least in biomasses. This is overall a mark of a faster nitrogen cycling and higher nitrogen

312 losses. This is in line with published results (Frank and Evans, 1997; Patra et al., 2006)

313 emphasizing cases of negative effects of herbivores on soil fertility. This also suggests that

314 our blocs 1 and 2 are overgrazed while a milder grazing pressure (blocs 3 and 4) do not lead

315 to such negative effects both in terms of (1) the switch form perennial to annuals grasses and

316 (2) the long-term soil fertility. 
We also predicted that the interaction between grazing intensity and grass species should impact nutrient cycling because species-specific effects on nitrogen cycling could be impacted by grazing, e.g. through differences in palatability. For example, perennial grasses could control efficiently nitrogen cycling and limit nitrogen losses only when they are not grazed intensively and have high biomasses. The absence of significant interactions between bloc and grass species for soil and biomass $\delta^{15} \mathrm{~N}$ further supports the idea that at a small scale 323 the impact of each grass species and bare soil drives the local nitrogen cycle and not grazing 324 or soil depth.

\subsection{Impacts of grasses, soil type and herbivory on nitrogen concentrations}

The more efficient nitrogen cycling fostered by perennial than by annual grasses and suggested by $\delta^{15} \mathrm{~N}$ values could have led to higher soil nitrogen concentrations for perennials than for annuals and bare soils. Perennial grasses have indeed been found to increase nitrogen content within their root systems (Jackson and Caldwell, 1993; Vinton and Burke, 1995).

330 Such a pattern was not found, and instead, soil nitrogen content depends on a complex 331 interaction between plant species and bloc. This pattern is difficult to explain in details. It 332 seems that the likely interactions between plant species impact on nutrient cycling and grazing 333 by cattle or soil depth is more influential for soil $\mathrm{N}$ concentration than for soil or biomass $334 \delta^{15} \mathrm{~N}$. The pattern must be linked to the fact that the likely reduced rate of nitrogen losses 335 under perennials does not necessarily lead to the buildup of the nitrogen stock within the soil 336 because perennial grasses also store a high amount of nitrogen in their root and shoot

337 biomass. Such an apparent discrepancy between fluxes and stocks was observed in Lamto 338 savanna in Ivory Coast where subpopulations of perennial grasses controlling or not 339 nitrification lead to 2-fold differences in grass biomass but not in soil $\mathrm{N}$ content (Lata et al., 340 1999). Our results on soil carbon concentration confirms the idea that in this savanna 
perennial grasses improve their own access to nitrogen but do not necessarily increase locally

342 soil C or $\mathrm{N}$ concentrations.

The pattern of nitrogen concentration within grass biomass is simpler: in leaves the

344 nitrogen concentration is higher in A. pseudapricus biomass than in the three other species, in

345 roots the nitrogen concentration is higher in the two annuals than in the two perennials. An

346 explanation could be that annual grasses tend to have higher nutrient concentrations than

347 perennials because they favor a quick growth (Craine et al., 2012; Garnier and Vancaeyzeele,

348 1994). This is supported by our root results but only partially by our leaf results: only one

349 annual (A. pseudapricus) has a higher leaf $\mathrm{N}$ concentration than the two perennials. Nitrogen

350 concentration depends on the availability of mineral nitrogen but is also linked to plant

351 ecophysiological traits such as the capacity to take up nitrogen or nitrogen use efficiency but

352 we so far do not have a clear explanation for the higher value observed for A. pseudapricus 353 leaves.

354 4.4. Relation between $\delta^{15} N$ and $N$ concentration in biomasses

355 Our results are consistent with the already described world-wide positive correlation 356 between $\delta^{15} \mathrm{~N}$ and $\mathrm{N}$ concentration in leaf biomasses (Craine et al., 2009b). In comparison to a 357 global data base, our leaf $\mathrm{N}$ concentrations are rather low (below $12 \mathrm{mg} \mathrm{g}^{-1}$ in most cases) and 358 our leaf $\delta^{15} \mathrm{~N}$ values are intermediate (between -2 and $4 \%$ in most cases). Our leaf $\delta^{15}$ values 359 are relatively high taking into account our rather low $\mathrm{N}$ concentration values (see Fig. 3c in 360 Craine et al., 2009b). These values are compatible with the global increase in $\delta^{15} \mathrm{~N}$ with the 361 mean annual temperature (our study site has a high mean temperature, about $28^{\circ} \mathrm{C}$ ) and the 362 global decrease with the mean annual precipitation (our study site has an intermediate mean 363 annual precipitation, about $1000 \mathrm{~mm} \mathrm{yr}^{-1}$ ) (Craine et al., 2009b). 
We expected different slopes for the relation between leaf $\mathrm{N}$ concentration and $\delta^{15} \mathrm{~N}$

365 between annuals and perennials. Somehow, a species for which $\mathrm{N}$ concentration increases 366 quicker with $\delta^{15} \mathrm{~N}$ is able to allocate more nitrogen to its leaves for a given rate of nitrogen 367 cycling and a given rate of openness of this cycling (Dijkstra et al., 2008; Templer et al., 368 2007). This species would be more efficient in terms of exploitation of nitrogen than species 369 with $\mathrm{N}$ concentrations increasing slower with $\delta^{15} \mathrm{~N}$. We did find a steeper relation between $\mathrm{N}$ 370 concentration and $\delta^{15} \mathrm{~N}$ for the annual species L. togoensis. However, we found the same 371 relation for the other annual and the two perennials. All factors influencing the $\delta^{15} \mathrm{~N}$, e.g. 372 mycorrhization and the type of mycorrhiza (Craine et al., 2009b), could explain this 373 difference between L. togoensis and the three other species. More information would be 374 needed to interpret this result.

375 Our results on the relation between root $\mathrm{N}$ concentration and root $\delta^{15} \mathrm{~N}$ are consistent 376 with the comparison of 90 grass species across four regions of the world (Craine et al., 2005).

377 This relation parallels the relation between leaf $\mathrm{N}$ concentration and leaf $\delta^{15} \mathrm{~N}$ but roots have 378 lower $\mathrm{N}$ concentrations than leaves so that the $\delta^{15} \mathrm{~N}$ increases more steeply with $\mathrm{N}$ 379 concentration for roots than for leaves. For roots the relation between $\mathrm{N}$ concentration and $380 \delta^{15} \mathrm{~N}$ is the same for the four species while, for leaves, L. togoensis displays a particular 381 relation. This suggests that the particular strategy of this species for $\mathrm{N}$ management aims at 382 increasing leaf $\mathrm{N}$ concentration and photosynthesis and not at improving the acquisition of 383 soil resources.

\section{5. Conclusion}

Our main conclusion remains that perennial grasses decrease soil and biomass ${ }^{15} \mathrm{~N}$ 386 signatures relative to annual grasses and bare soil. This confirms the usefulness of ${ }^{15} \mathrm{~N}$ as an 387 integrative tool to asses nitrogen cycling (Kahmen et al., 2008; Templer et al., 2007). This 
suggests that perennials better control nitrogen cycling through a slower cycling and lower rates of nitrogen losses through leaching and denitrification: perennial grasses would have evolved particular mechanisms to improve nitrogen cycling in their favor, which would ultimately feedback on their growth allowing them to accumulate more biomass. These arguments are further supported by the fact that annual grasses can be viewed as $r$ or ruderal species in comparison to perennial grasses (Grime, 1977, 2001). In annuals, evolution should have selected strategies that favor the immediate use of mineral resources. Perennials, on the contrary, should benefit from strategies allowing them to make the best use of mineral resources on the long term, which should lead to lower rates of nutrient cycling and lower rates of nutrient losses.

The mechanisms evolved by perennials could be involved in the high primary productivity of Guinean humid savannas (Boudsocq et al., 2009; Gignoux et al., 2006) and could increase the primary productivity of Sudanian savannas dominated by perennial grasses (for example, here in Burkina Faso). In turn, our results are consistent with the idea that annual grasses are a mark of soil and vegetation degradation, and that annual grasses tend to replace perennials in less fertile soil conditions and after over-grazing (Belsky and Blumenthal, 1997; Burke et al., 1998; César, 1989; Derner et al., 1997; Rossignol et al., 2006). Here, because the higher cattle pressure occurs in the area of shallower soils it was $a$ priori not possible to disentangle their possible effects, which should be possible with an experimental approach excluding cattle from some patches. Anyway, our results suggest that soil or biomass ${ }^{15} \mathrm{~N}$ signatures could be used as a diagnostic tool for the degradation of pastures and the fertility of their soils.

Acknowledgments. Lambiénou Yé has been financed by the AIRD program BSTD for his PhD. We thank the LEMSAT laboratory in Dakar for the facilities we were given for soil and 
412 biomass analyses. We also thank Roger Kissou and Saïbou Nignan for their efficient help

413 during the soil characterization and installation of the plots.

\section{References}

415 Abadín, J., González-Prieto, S.J., Carballas, T., 2010. Relationships among main soil properties and three N availability indices. Plant and Soil 339, 193-208.

417 Abbadie, L., Lata, J.-C., 2006. Nitrogen dynamics in the soil-plant system, in: Abbadie, L., 418 Gignoux, J., Le Roux, X., Lepage, M. (Eds.), Lamto. Structure, functioning, and dynamics of a savanna ecosystem. Springer, pp. 335-364.

Abbadie, L., Mariotti, A., Menaut, J.-C., 1992. Independance of savanna grasses from soil organic matter for their nitrogen supply. Ecology 73, 608-613.

Aranibar, J.N., Anderson, I.C., Epstein, H.E., Feral, C.J.W., Swap, R.J., Ramontsho, J., Macko, S.A., 2008. Nitrogen isotope composition of soils, C-3 and C-4 plants along land use gradients in southern Africa. Journal of Arid Environments 72, 326-337.

Bardgett, R.D., Wardle, D.A., 2003. Herbivore-mediated linkages between aboveground and belowground communities. Ecology 84, 2258-2268.

Belsky, A.J., Blumenthal, D.M., 1997. Effects of livestock grazing on stand dynamics and soils in upland forests of the interior West. Conservation Biology 11, 315-327.

Bilgo, A., Masse, D., Sall, S., Serpantié, G., Chotte, J.L., Hien, V., 2006. Chemical and microbial properties of semiarid tropical soils of short-term fallows in Burkina Faso, West Africa. Biology and Fertility of Soils 43, 313-320.

Boudsocq, S., Lata, J.C., Mathieu, J., Abbadie, L., Barot, S., 2009. Modelling approach to analyze the effects of nitrification inhibition on primary production. Functional Ecology 23, 220-230. 
435 Boutton, T.W., Archer, S.R., Midwood, A.J., Zitzer, S.F., Bol, R., 1998. $\delta{ }^{13} \mathrm{C}$ values of soil organic carbon and their use in documenting vegetation change in a subtropical savanna ecosystem. Geoderma 82, 5-41.

438 Breman, H., De Ridder, N., 1991. Manuel sur les pâturages des pays sahéliens. Karthala.

439 Burke, I.C., Reiners, W.A., Schimel, D.S., 1998. Plant-soil interactions in temperate grasslands. Biogeochemistry 42, 121-143.

441 César, J., 1989. L'influence de l'exploitation sur la pérennité des pâturages de savane II. Rôle du système racinaire dans la dégradation du pâturage. Fourrage 120, 383-392.

Chapman, K.S., Langley, J.A., Hart, S.C., Koch, G.W., 2006. Plants actively control nitrogen cycling: uncorking the microbial bottleneck. New Phytologist 169, 27-34.

Craine, J.M., 2009. Resource strategies of wild plants. Princeton University Press, Princeton, New Jersey.

Craine, J.M., Ballantyne, F., Peel, M., Zambatis, N., Morrow, C., Stock, W.D., 2009a. Grazing and landscape controls on nitrogen availability across 330 South African savanna sites. Austral Ecology 34, 731-740.

Craine, J.M., Elmore, A.J., Aidar, M.P.M., Bustamante, M., Dawson, T.E., Hobbie, E.A., R.A., Welker, J.M., Wright, I.J., 2009b. Global patterns of foliar nitrogen isotopes and their relationships with climate, mycorrhizal fungi, foliar nutrient concentrations, and nitrogen availability. New Phytologist 183, 980-992.

Craine, J.M., Lee, W.G., Bond, W.J., Williams, R.J., Johnson, L.C., 2005. Environmental constraints on a global relationship among leaf and root traits of grasses. Ecology 86, 12-19. 
Craine, J.M., Towne, E.G., Ocheltree, T.W., Nippert, J.B., 2012. Community traitscape of foliar nitrogen isotopes reveals $\mathrm{N}$ availability patterns in a tallgrass prairie. Plant and Soil 356, 395-403.

Danso, S.K.A., Hardarson, I.G., Zapata, F., 1993. Misconceptions and practical problems in the use of ${ }^{15} \mathrm{~N}$ soil enrichment techniques for estimating $\mathrm{N}_{2}$ fixation. Plant and Soil $152,25-52$.

de Mazancourt, C., Loreau, M., Abbadie, L., 1998. Grazing optimization and nutrient cycling: when do herbivores enhance plant production? Ecology 79, 2242-2252.

Derner, J.D., Briske, D.D., Boutton, T.W., 1997. Does grazing mediate soil carbon and nitrogen accumulation beneath $\mathrm{C}_{4}$, perennial grasses along an environmental gradient? Plant and Soil 191, 147-156.

Dijkstra, P., LaViolette, C.M., Coyle, J.S., Doucett, R.R., Schwartz, E., Hart, S.C., Hungate, B.A., 2008. $\mathrm{N}-15$ enrichment as an integrator of the effects of $\mathrm{C}$ and $\mathrm{N}$ on microbial metabolism and ecosystem function. Ecology Letters 11, 389-397.

Elbeltagy, A., Nishioka, K., Sato, T., Suzuki, H., Ye, B., Hamada, T., Isawa, T., Mitsui, H., Minamisawa, K., 2001. Endophytic colonization and in planta nitrogen fixation by a Herbaspirillum sp. isolated from wild rice species. Applied and environmental microbiology 67, 5285-5293.

Frank, D.A., Evans, R.D., 1997. Effects of native grazers on grassland $\mathrm{N}$ cycling in Yellowstone National Park. Ecology 78, 2238-2248.

Frank, D.A., Groffman, P.M., Evans, R.D., Tracy, B.F., 2000. Ungulate stimulation of nitrogen cycling and retention in Yellowstone Park grasslands. Oecologia 123, 116121. 
Garnier, E., Vancaeyzeele, S., 1994. Carbon and nitrogen content of congeneric annual and perennial grass species: relationships with growth. Plant, Cell \& Environment 17, 399407.

Gignoux, J., Mordelet, P., Menaut, J.-C., 2006. Biomass cycle and primary production, in: Abbadie, L., Gignoux, J., Le Roux, X., Lepage, M. (Eds.), Lamto : Structure, functioning and dynamics of a savanna ecosystem, pp. 115-138.

Grime, J.P., 1977. Evidence for the existence of three primary strategies in plants and its relevance to ecological and evolutionary theory. American Naturalist 111, 1169-1194.

Grime, J.P., 2001. Plant strategies, vegetation processes, and ecosystem properties. Wiley, John Wiley, New York, USA.

Hobbie, S.E., 1992. Effects of plant species on nutrient cycling. Trends in Ecology and Evolution 7, 336-339.

Jackson, R.B., Caldwell, M.M., 1993. Geostatistical patterns of soil heterogeneity around individual perennial plants. Journal of Ecology 81, 683-692.

Joffre, R., 1990. Plant and soil nitrogen dynamics in mediterranean grasslands: a comparison of annual and perennial grasses. Oecologia 85, 142-149.

Kahmen, A., Wanek, W., Buchmann, N., 2008. Foliar $\delta^{15} \mathrm{~N}$ values characterize soil $\mathrm{N}$ cycling and reflect nitrate or ammonium preference of plants along a temperate grassland gradient. Oecologia 156, 861-870.

Knops, J.M.H., Bradley, K.L., Wedin, D.A., 2002. Mechanisms of plant species impacts on ecosystem nitrogen cycling. Ecology Letters 5, 454-466.

Kriszan, M., Amelung, W., Schellberg, J., Gebbing, T., Kühbauch, W., 2009. Long-term changes of the $\delta^{15} \mathrm{~N}$ natural abundance of plants and soil in a temperate grassland. Plant and Soil 325, 157-169. 
Lata, J.-C., Degrange, V., Raynaud, X., Maron, P.-A., Lensi, R., Abbadie, L., 2004. Grass populations control nitrification in savanna soils. Functional Ecology 18, 605-611.

Lata, J.-C., Durand, J., Lensi, R., Abbadie, L., 1999. Stable coexistence of contrasted nitrification statuses in a wet tropical savanna ecosystem. Functional Ecology 13, 762768.

Mariotti, A., Germon, J.C., Hubert, P., Kaiser, P., Letolle, R., Tardieux, A., Tardieux, P., 1981. Experimental determination of nitrogen kinetic isotope fractionation: Some principles; illustration for the denitrification and nitrification processes. Plant and Soil $62,413-430$.

Nacro, H.B., Larré-Larrouy, M.-C., Mariotti, A., Feller, C., Abbadie, L., 2004. Natural nitrogen-15 abundance and carbohydrate content and composition of organic matter particle-size fractions from a sandy soil. 40, 171-177.

Nadelhoffer, K., Shaver, G., Fry, B., Giblin, G., Johnson, L., McKane, R., $1996 .{ }^{15} \mathrm{~N}$ natural abundances and $\mathrm{N}$ use by tundra plants. Oecologia 107, 386-394.

McNaughton, S.J., Banykwa, F.F., McNaughton, M.M., 1997. Promotion of the cycling of diet-enhencing nutrients by African grazers. Science 278, 1798-1800.

Patra, A.K., Abbadie, L., Clays-Josserand, A., Degrange, V., Graystone, S.J., Louault, F., Mahmood, S., Nazaret, S., Phillipot, L., Poly, F., Prosser, J.I., Le Roux, X., 2006. Effects of management regime and plant species on the enzyme activity and genetic structure of $\mathrm{N}$-fixing, denitrifyning and nitrifying bacterial communities in grassland soils. Environmental Microbiology 8, 1005-1016.

$\mathrm{R}$ development core team, 2010. R: a language and environment for statistical computing $\mathrm{R}$ foundation for statistical computing, Vienna.

Robinson, D., 2001. $\delta^{15} \mathrm{~N}$ as an integrator of the nitrogen cycle. Trends in Ecology and Evolution 16, 153-162. 
531 Rossignol, N., Bonis, A., Bouzillé, J.-B., 2006. Consequence of grazing pattern and vegetation structure on the spatial variations of net $\mathrm{N}$ mineralisation in a wet grassland. Applied Soil Ecology 31, 62-72.

534 Somé, N.A., 1996. Les systèmes écologiques post-culturaux de la zone soudanienne (Burkina Faso): structure spatio-temporelle des communautés végétales et évolution des caractères pédologiques. Université Pierre et Marie Curie (Paris VI), Paris, France.

Staddon, P.L., 2004. Carbon isotopes in functional soil ecology. Trends in ecology \& evolution $19,148-154$.

Subbarao, G.V., Rondon, M., Ito, O., Ishikawa, T., Rao, I.M., Nakahara, K., Lascano, C., Berry, W.L., 2007a. Biological nitrification inhibition (BNI)-is it a widespread phenomenon? Plant and Soil 294, 5-18.

Subbarao, G.V., Wang, H.Y., Ito, O., Nakahara, K., Berry, W.L., 2007b. $\mathrm{NH}_{4}{ }^{+}$triggers the synthesis and release of biological nitrification inhibition compounds in Bracharia humicola roots. Plant and Soil 290, 245-257.

Templer, P.H., Arthur, M.A., Lovett, G.M., Weaters, K.C., 2007. Plant and soil natural abundance $\delta^{15} \mathrm{~N}$ : indicators of the relative rates of nitrogen cycling in temperate forest ecosystems. Oecologia 153, 399-406.

Templer, P.H., Lovett, G.M., Weathers, K.C., Findlay, S.E., Dawson, T.E., 2005. Influence of tree species on forest nitrogen retenton in the Catskill mountains, New York, USA. Ecosystems 8, 1-16.

551 Templer, P.H., Silver, W.L., Pett-Ridge, J., DeAngelis, K.M., Firestone, M.K., 2008. Plant and microbial controls on nitrogen retention and loss in a humid tropical forest. Ecology 89, 3030-3040.

554 Vinton, M.A., Burke, I.C., 1995. Interactions between individual plant species and soil nutrient status in shortgrass steppe. Ecology 76, 1116-1133. 
556 Wang, L., D'Odorico, P., Ries, L., Macko, S.A., 2010. Patterns and implications of plant-soil $\delta^{13} \mathrm{C}$ and $\delta^{15} \mathrm{~N}$ values in African savanna ecosystems. Quaternary Research 73, 77-83.

558 Wardle, D.A., Barker, G.M., Yeates, G.W., Bonner, K.I., Ghani, A., 2001. Introduced 559 browsing mammals in New Zealand natural forests: aboveground and belowground consequences. Ecological Monographs 74, 587-614.

561

562

563

564

565 
566 Table 1: Analyses of variance of soil $\mathrm{N}$ concentration and $\delta^{15} \mathrm{~N}$ and $\mathrm{C}$ concentration. The 567 effect of the bloc, the grass species and the interaction between the two are tested. F values 568 are given together with an indication of significance. The last line indicates the direction of 569 effects through the ordering of treatments. When the interaction is significant this line gives 570 the results of ANOVAs analysing separately the bloc effect for each species. **, $\mathrm{P}<0.01$; $571 * * *, \mathrm{P}<0.001$; ns, no significant effect; df, degree of freedom; 1, 2, 3, 4, blocs; AA, A. 572 ascinodis; AG, A. gayanus; AP, A. pseudapricus; LT, L. togoensis; BS, bare soil. 573

\begin{tabular}{lllll}
\hline & Df & Soil $\delta^{15} \mathrm{~N}$ & Soil N & Soil C \\
\hline Bloc & 3 & 1.24 & 2.14 & 0.61 \\
\hline Species & 4 & $4.34^{* *}$ & 0.57 & 1.04 \\
\hline BlocXSpecies & 12 & - & $2.68^{*}$ & $2.09^{* *}$ \\
\hline $\mathrm{R}^{2}$ & & 0.33 & 0.58 & 0.57 \\
\hline Direction & of & $\mathrm{AP}, \mathrm{LT}, \mathrm{BS}$ & In AA: 1, 3 & In AA: ns \\
effects & & $>\mathrm{AA}, \mathrm{AG}$ & $>2,4$ & In AG: ns \\
& & & In AG: ns & In AP: $3,4>1$, \\
& & & In AP: 3,4 & 2 \\
& & & $>1,2$ & In LT: $1,4>2$, \\
& & & In LT: 1,4 & 3 \\
& & & In BS: ns & \\
& & &
\end{tabular}


576 Table 2: Analyses of variance of root and leaf $\mathrm{N}$ concentration and $\delta^{15} \mathrm{~N}$. The effect of the

577 bloc, the grass species and the interaction between the two were tested. The interaction was

578 never significant and was thus removed from the model. F values are given together with an

579 indication of significance. The last line indicates the direction of effects through the ordering

580 of treatments. When the interaction is significant this line gives the results of ANOVAs

581 analysing separately the bloc effect for each species. **, $\mathrm{P}<0.01$; ***, $\mathrm{P}<0.001$; ns, no

582 significant effect; df, degree of freedom; 1, 2, 3, 4, blocs; AA, A. ascinodis; AG, A. gayanus;

583 AP, A. pseudapricus; LT, L. togoensis; BS, bare soil.

584

\begin{tabular}{llllll}
\hline & Df & Root $\delta^{15} \mathrm{~N}$ & Root $\mathrm{N}$ & Leaf $\delta^{15} \mathrm{~N}$ & Leaf N \\
\hline Bloc & 3 & $3.75^{*}$ & $14.10^{* * *}$ & $4.70^{* *}$ & $3.10^{*}$ \\
\hline Species & 3 & $13.88^{*}$ & $44.92^{* * *}$ & $8.79 * * *$ & $16.63^{* * *}$ \\
\hline $\mathrm{R}^{2}$ & & 0.74 & 0.88 & 0.73 & 0.70 \\
\hline Direction & of & AP, LT & AP, LT & AP $>$ LT, AA, & AP $>$ LT, AA, \\
effects & & $>$ AA, AG & $>$ AA, AG & AG & AG \\
& & $1>3,4$ & $1,2,3>4$ & $1,2>4$ & $2,3>4$ \\
& & $2>3$ & & \\
\hline
\end{tabular}


588 Table 3: Means and standard deviations (in parentheses) for biomass and soil $\mathrm{N}$ 589 concentrations $\left(\mathrm{mg} \mathrm{g}^{-1}\right)$ and $\delta^{15} \mathrm{~N}(\%)$.

590

\begin{tabular}{lllllll}
\hline & Soil $\delta{ }^{15} \mathrm{~N}$ & Soil N & Root $\delta{ }^{15} \mathrm{~N}$ & Root N & Leaf $\delta^{15} \mathrm{~N}$ & Leaf N \\
\hline A. ascinodis & $3.98(0.55)$ & $2.09(2.76)$ & $-0.72(0.86)$ & $2.52(0.31)$ & $-0.59(1.32)$ & $6.20(1.95)$ \\
\hline A. gayanus & $3.88(0.60)$ & $2.03(2.21)$ & $-0.99(0.73)$ & $2.71(0.47)$ & $-0.30(0.52)$ & $7.41(1.17)$ \\
\hline A. pseudapricus & $4.38(0.34)$ & $3.01(2.37)$ & $2.60(1.78)$ & $4.09(0.45)$ & $2.74(2.06)$ & $10.55(2.33)$ \\
\hline L. togoensis & $4.55(0.43)$ & $2.84(2.75)$ & $1.26(1.80)$ & $3.65(0.41)$ & $0.67(1.92)$ & $6.32(0.85)$ \\
\hline Bare soil & $4.56(0.44)$ & $2.94(2.27)$ & - & - & - & - \\
\hline
\end{tabular}

591

592

593 
596 Figure 1: Boxplots for $\mathrm{N}$ content and $\delta^{15} \mathrm{~N}$ of the soil, the roots and the leaves as a function of 597 blocs and grass species. Medians are displayed together with 25 th and 75 th quartiles. 598 Treatments and combinations of treatments that are displayed correspond to significant effects 599 as determined by the ANOVAs (Table 1). Different letters denote significant differences 600 between treatments. When the interaction between bloc and grass species is significant 601 different letters denote differences between blocs within a grass species. 1, 2, 3, 4, blocs; $A$. 602 pseuda stands for A. pseudapricus.

603

604 Figure 2: Boxplots for soil C concentration. Medians are displayed together with 25th and 605 75th quartiles. Treatments and combinations of treatments that are displayed correspond to 606 significant effects as determined by the ANOVAs (Table 2). Different letters denote 607 significant differences between treatments. When the interaction between bloc and grass 608 species is significant different letters denote differences between blocs within a grass species. 609 1, 2, 3, 4, blocs; A. pseuda stands for A. pseudapricus.

610

611 Fig. 3 Regression between biomass $\delta^{15} \mathrm{~N}$ and $\mathrm{N}$ concentrations. The regression is significantly 612 different between roots and leaves, and within leaves between L. togoensis (LT leaves) and 613 the 3 other species (Other leaves). Circles, roots of the four species; crosses, L. togoensis 614 leaves; plus, A. pseudapricus leaves ; filled triangle, A. ascinodis leaves; triangle, A. gayanus 615 leaves. 
Fig 1
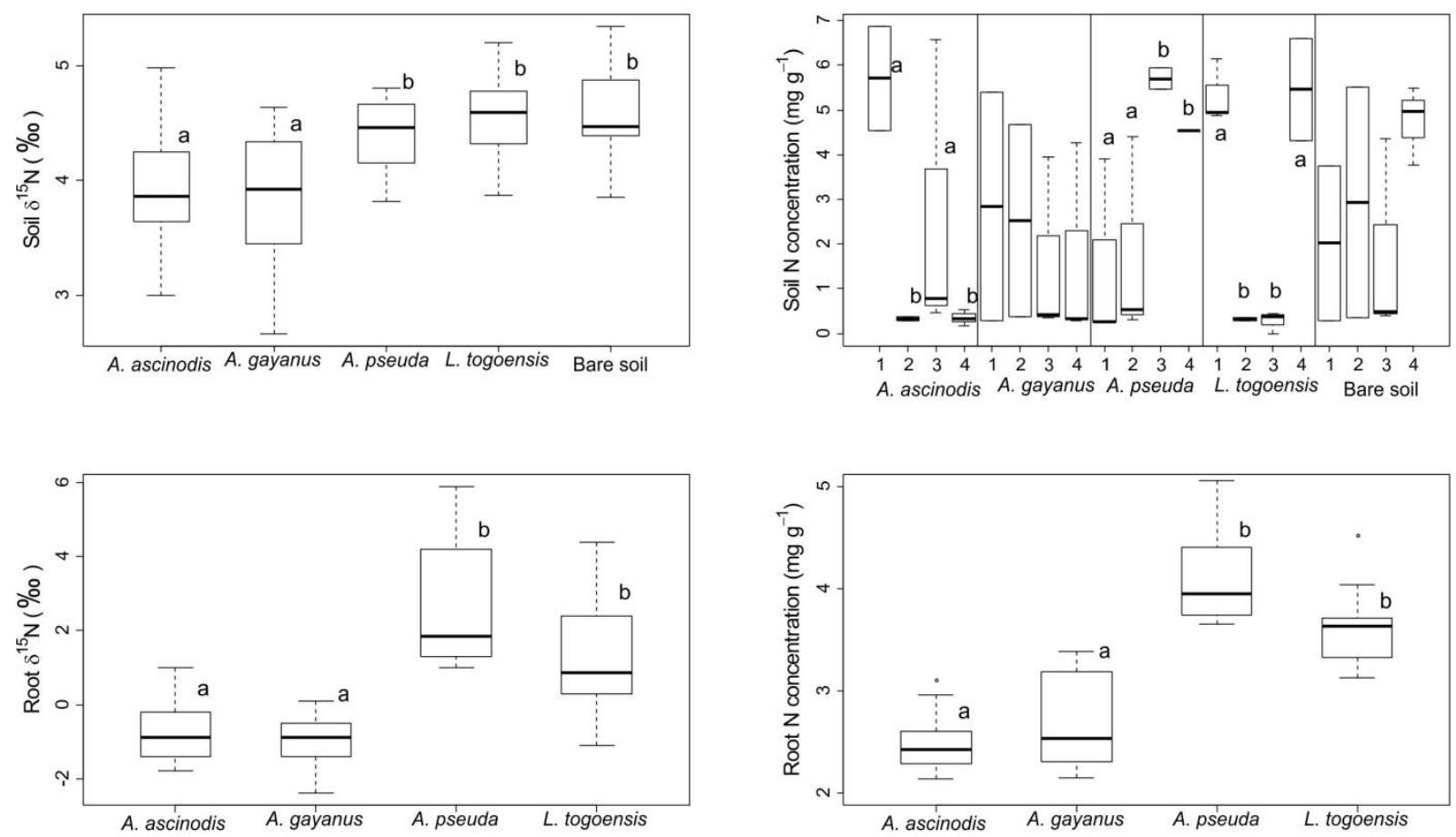

619
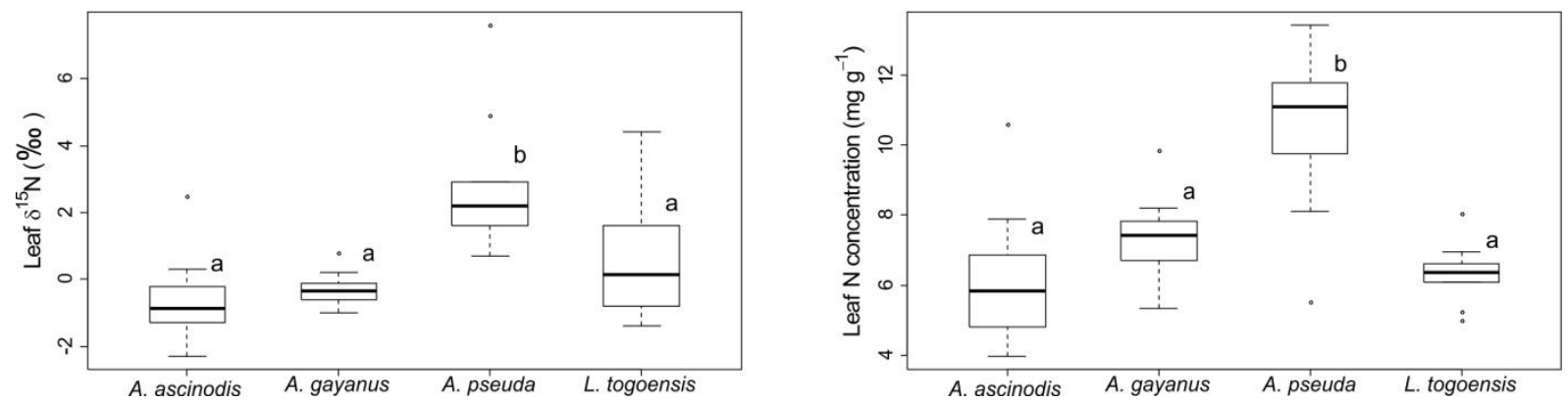

620 
621 Fig 2

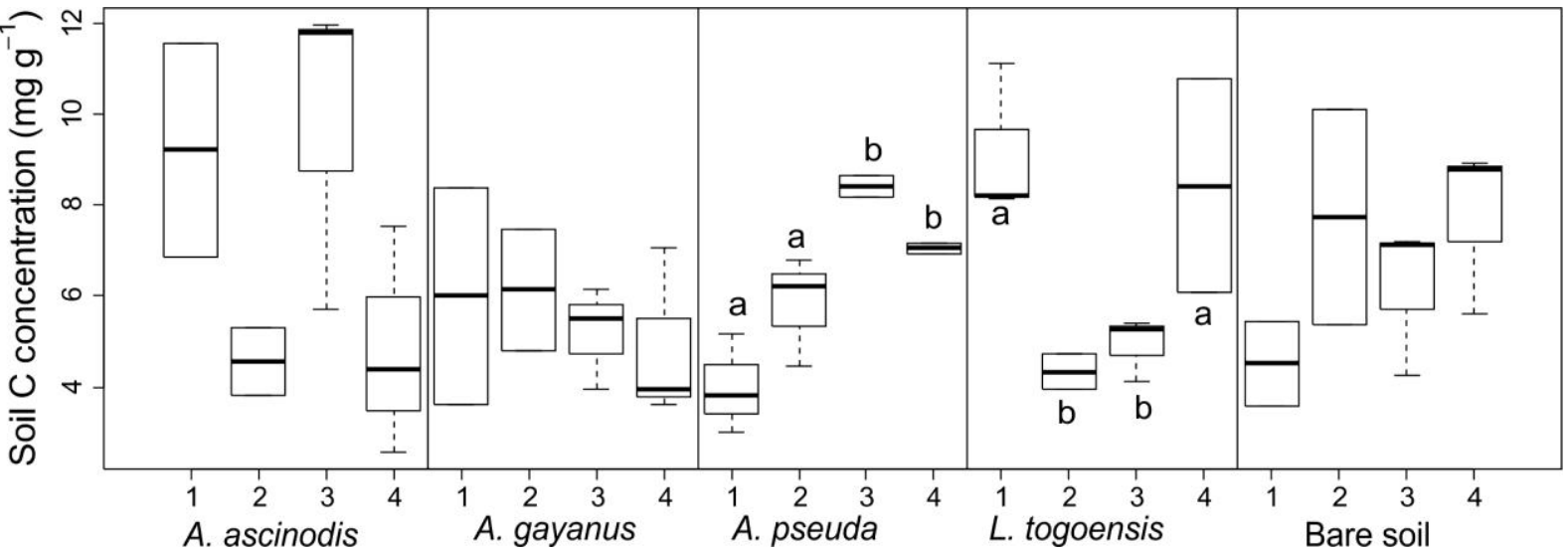

623

624

625 
$627 \quad$ Fig 3

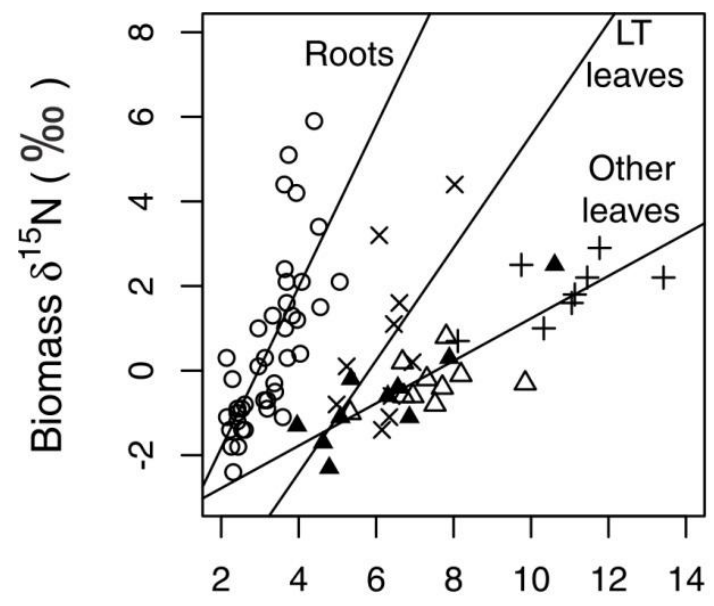

628 Biomass $\mathrm{N}$ concentration ( $\mathrm{mg} \mathrm{g}^{-1}$ )

629

630

631 